NBER WORKING PAPER SERIES

THE LONG RUN IMPORTANCE OF SCHOOL QUALITY

\author{
Eric A. Hanushek \\ Working Paper 9071 \\ http://www.nber.org/papers/w9071 \\ NATIONAL BUREAU OF ECONOMIC RESEARCH \\ 1050 Massachusetts Avenue \\ Cambridge, MA 02138 \\ July 2002
}

Helpful comments were provided by Lance Lochner and Macke Raymond. This work was supported by funding from the Packard Humanities Institute. The views expressed herein are those of the author and not necessarily those of the National Bureau of Economic Research.

(C) 2002 by Eric A. Hanushek. All rights reserved. Short sections of text, not to exceed two paragraphs, may be quoted without explicit permission provided that full credit, including $\mathbb{C}$ notice, is given to the source. 
The Long Run Importance of School Quality

Eric A. Hanushek

NBER Working Paper No. 9071

July 2002

JEL No. I2, H4, J3, E6

\begin{abstract}
The role of schooling and school quality in the economy has become very confused, in part because of attempts to argue different positions on educational policy. Research demonstrates that school quality has a strong impact on individual earnings, on the distribution of income, and on overall economic growth. In contrast to these long run factors, today's school quality has little to do with current business cycles or unemployment rates. This paper emphasizes the importance of school quality - measured by math and science test scores - on economic growth. While U.S. growth has been strong over the 20th century, it has not been the result of high quality schooling relative to that in other countries. Instead other factors such as open labor markets and high quality colleges and universities appear to have masked the mediocre performance by U.S. students.
\end{abstract}

Eric A. Hanushek Hoover Institution Stanford University Stanford, CA 94305-6010 and NBER hanushek@stanford.edu 


\title{
The Long Run Importance of School Quality
}

\author{
By Eric A. Hanushek
}

The early 1990s saw the height of the East Asian miracle. The economies of Japan, Korea, and other countries of the region were expanding at rates that dwarfed those of the United States and OECD countries. Simple projections saw these economies as overtaking and surpassing the U.S. economy within short periods of time. And, in the soul searching that accompanied concerns about this blow to national pride, new attention was focused on the U.S. educational system. Thus, when the East Asian countries lost their luster, many educators breathed a sigh of relief. The U.S. economy entered into a record breaking period of high employment and recession free growth during the 1990s, while Japan found high unemployment and recession to be a persistent fixture of the period. The economic trends have, however, been frequently misinterpreted. Many commentators appear all too eager to jump on almost any economic news and to link it to today's schools. Any pattern of bad economic results demonstrates to some that the education system is broken, while any economic good news provides others with confirmation of the superiority of the U.S. education system. Sorting out the various facets of interaction of the education system with the economy is important because it focuses attention on some important policy issues that will have substantial impact on our future well-being while eliminating some of the spurious but oft-repeated arguments.

Research shows an increased importance of worker skills. This increased importance of skills appears in its effects on the earnings of individuals and on the subsequent distribution of income in the economy. And, central to the discussion here, worker skills and school quality importantly influence growth of the national economy. The irrefutable fact is that the pattern of economic growth has huge ramifications for society, so that things that affect growth deserve special attention. 
The education system is central to the development of skills, a fact long recognized by parents, policy makers, and educators. And, over the past century, the United States led the world in the expansion of its education system. This expansion education has contributed to the preeminent position of the U.S. economy in the world. Nonetheless, concerns exist about the future. The concerns revolve around the knowledge of graduates and the quality of the schools. There is little evidence that the K-12 education system in the United States is in fact competitive in the world economy or that it can be counted on to fuel future U.S. economic growth. These are matters that we should take very seriously.

The fact that other aspects of the U.S. economy are sufficient to compensate for the mediocre quality of its schools should not be taken as justification for allowing the current state to continue. The quality of schooling has a clear impact on both individual earnings and the growth of the overall economy, and the available evidence suggests that improvements in the schools would translate into substantial long run gains.

\section{Observations about the Economy and School Quality}

Confusion about the relationship between schooling and economic outcomes has existed for some time. Part of the muddled ideas can be related to the language and perspective of $A$ Nation at Risk (National Commission on Excellence in Education (1983)). Written during a recession, it implied that the general state of the economy could be directly traced to performance of the educational system. A variety of writers who have taken the position that there are no overall problems with U.S. schools have picked up this rhetoric coupled with improved economic conditions. For example, Alfie Kohn (2000), responding specifically to A Nation at Risk, writes:

"As proof of the inadequacy of U.S. schools, many writers and public officials pointed to the sputtering condition of the U.S. economy. As far as I know, none of them subsequently apologized for offering a mistaken and unfair attack on our 
educational system once the economy recovered, nor did anyone credit teachers for the turnaround."

And, Gerald Bracey (2002) takes the argument one step further. Noting that a variety of people from before and after $A$ Nation at Risk had argued for improving schools in order to maintain U.S. economic strength, he says, "None of these fine gentlemen provided any data on the relationship between the economy's health and the performance of schools. Our long economic boom suggests there isn't one - or that our schools are better than the critics claim."

With the confusion created by the statements of both politicians and educational commentators, it is useful to review what we know about the relationship between education and the economy. Economists have devoted considerable attention to understanding how "human capital" affects a variety of economic outcomes. The underlying notion is that individuals make investment decisions in themselves through schooling and other routes. The accumulated skills that are relevant for the labor market from these investments over time represent the human capital of an individual. The investments made to improve skills then return future economic benefits in much the same way that investing in a set of machines (physical capital) by a firm returns future production and income. In the case of public education, parents and public officials act as trustees for their children in setting many aspects of the investment paths.

In looking at human capital and its implications for future outcomes, economists are frequently agnostic about where these skills come from or how they are produced. While we return to this below, it is nonetheless commonly presumed that formal schooling is one of several important contributors to the skills of an individual and to human capital. It is not the only factor. Parents, individual abilities, and friends undoubtedly contribute. Schools nonetheless have a special place because they are most directly affected by public policies. For this reason we frequently emphasize the role of schools.

The general human capital perspective immediately makes it evident that the real issues are ones of long run outcomes. Future incomes of individuals are related to their past 
investments. It is not their income while in school or their income in their first job. Instead it is their income over their working life.

The distribution of income in the economy similarly involves both the mixture of people in the economy and the pattern of their incomes over their lifetime. Specifically, most measures of how income and well-being vary in the population do not take into account the fact that some of the low income people have low incomes only because they are just beginning a career. Their lifetime income is likely to be much larger as they age, gain experience, and move up in their firms and career. Importantly, any noticeable effects of the current quality of schooling on the distribution of skills and income will only be realized years in the future, when those currently in school become a significant part of the labor force.

Importantly, if interested in how the skills of workers affect the overall economy, one cannot just consider the new graduates that count; it is the mass of older workers who are the current driving force of the economy. In other words, most workers in the economy were educated years and even decades in the past - and they are the ones that have the most impact on current levels of productivity and growth if for no reason other than the fact that they represent the larger share of active workers.

While many noneconomists have difficulty in sorting out long term growth from short run business cycles, it is absolutely necessary to do so in this case. In particular, if we look at the course of the business cycle - the current levels of economic activity relative to what is potentially possible - we would not expect, say, the level of unemployment at any point in time to relate at all to the current quality and outcomes of our schools. Unemployment reflects aggregate demand for workers relative to the aggregate supply of workers, and it is influenced by a wide variety of aspects of the private economy and of government activities. Monetary and fiscal policy as opposed to current school programs and spending drive the business cycle.

It is true that, for any level of unemployment, young workers will typically have a higher rate of unemployment. This phenomenon reflects the generally lower experience levels and 
degree of attachment of young workers with any firms. And differences in the skills and preparation of individuals clearly influence who suffers unemployment at any point in time. But the overall level of unemployment cannot be influenced significantly by those currently in school or recently graduating from school.

In simplest terms, the contemporary tracking of the economy - either at an individual level or at an aggregate level - will not tell us much about the schools of today. Thus, for example, the fact that unemployment is lower on any given day in the United States as opposed to Japan or Korea says virtually nothing about the relative quality of schools in the different countries. It might instead say something about the quality of current fiscal and monetary policy or about the extent of labor market and trade barriers across countries. And, it might even bear some relationship to the human capital investments made in past periods - when the full spectrum of workers in the labor force was attending schools and investing in skills. Yet it stops short of providing an indication of school outcomes and quality as developed by the policies and operations of today's schools.

\section{Evidence on Economic Impact of School Quality}

Much of the early development of empirical work on human capital rightfully concentrated on the role of school attainment, that is, the quantity of schooling. This focus was natural. The revolution in the United States during the $20^{\text {th }}$ century was universal schooling. Moreover, quantity of schooling is easily measured, and data both over time and across individuals on years attained are readily available. Today, however, policy concerns revolve much more around quality issues than quantity issues. The completion rates for high school and college have been roughly constant for a quarter of a century. On the other hand, the standards movement has focused on what students know as they progress through schools. The debates and court cases about "adequacy" highlight concerns about both the distribution of outcomes and the 
levels of performance that are achieved. Issues about what students know when they graduate from high school are specifically ones of quality, not quantity of schooling.

\section{Individual productivity and incomes}

It is useful to establish some facts about the value of "quality." One of the challenges in understanding the impact of quality differences in human capital has been simply knowing how to measure quality. Much of the discussion of quality - in part related to new efforts to provide better accountability - has identified cognitive skills as the important dimension. And, while there is on-going debate about the testing and measurement of these skills, most parents and policy makers alike accept the notion that cognitive skills are a key dimension of schooling outcomes. But it still remains an issue about how important any such measured quality might be, particularly if we are moving toward paying more attention to tested performance of students.

Until recently, little comprehensive data have been available about differences in cognitive skills and any related economic outcomes. Such data are now becoming available so that some of the fundamental questions about quality measurement can be addressed.

There is mounting evidence that quality - generally measured by test scores - is positively related to individual earnings, productivity, and economic growth. While focusing on the estimated returns to years of schooling, early studies of wage determination tended to indicate relatively modest impacts of variations in cognitive ability after holding constant quantity of schooling. More recent direct investigations of cognitive achievement, however, have suggested generally larger labor market returns to measured individual differences in cognitive achievement. For example, Bishop (1989, 1991), O'Neill (1990), Grogger and Eide (1993), Blackburn and Neumark (1993, 1995), Murnane, Willett, and Levy (1995), Neal and Johnson (1996), Murnane et al. (2000), Altonji and Pierret (2001), and Murnane et al. (2001) each find 
that the earnings advantages to higher achievement on standardized tests are quite substantial. ${ }^{1}$

While these analyses emphasize different aspects of individual earnings, they typically find that measured achievement has a direct impact on earnings after allowing for differences in the quantity of schooling, the experiences of workers, and other factors that might also influence earnings. In other words, higher quality as measured by tests similar to those currently being used in accountability systems around the country is closely related to individual productivity and earnings.

An additional part of the return to school quality comes through continuation in school. There is substantial United States evidence that students who do better in school, either through grades or scores on standardized achievement tests, tend to go farther in school (see, for example, Dugan (1976); Manski and Wise (1983)). Rivkin (1995) finds that variations in test scores capture a considerable proportion of the systematic variation in high school completion and in college continuation, so that test score differences can fully explain black-white differences in schooling. Bishop (1991) and Hanushek, Rivkin, and Taylor (1996), in considering the factors that influence school attainment, find that individual achievement scores are highly correlated with continued school attendance. Neal and Johnson (1996) in part use the impact of achievement differences of blacks and whites on school attainment to explain racial differences in

\footnotetext{
${ }^{1}$ These results are derived from quite different approaches. All of the investigations begin with a general analysis of the determination of individual earnings and then provide information about the separate contribution of measured cognitive skills. Bishop (1989) considers the measurement errors inherent in most testing situations and demonstrates that careful treatment of that problem has a dramatic effect on the estimated importance of test differences. O'Neill (1990), Grogger and Eide (1993), Bishop (1991), and Neal and Johnson (1996) on the other hand simply rely upon more recent labor market data along with more representative sampling and suggest that the earnings advantage to measured skill differences is larger than that found in earlier time periods and in earlier studies (even without correcting for test reliability). Murnane, Willett, and Levy (1995), considering a comparison over time, demonstrate that the results of increased returns to measured skills hold across simple analysis and error-corrected estimation. Murnane et al. (2000) and Murnane et al. (2001) employ representative samples but also introduce other measures of individual skill. Blackburn and Neumark $(1993,1995)$ do not focus on ability per se but concentrate on possible biases in the estimated return to years of schooling. Altonji and Pierret (2001) show that the rewards to cognitive skills increase with experience as employers have an opportunity to observe skill differences. This finding has clear implications for other research into the effects of measured skills.
} 
incomes. Behrman et al. (1998) find strong achievement effects on both continuation into college and quality of college; moreover, the effects are larger when proper account is taken of the various determinants of achievement. Hanushek and Pace (1995) find that college completion is significantly related to higher test scores at the end of high school. Each of these investigations highlights the independent role of achievement in affecting the schooling choices and investment decisions of individuals.

The role of schooling and human capital in altering the distribution of incomes in society has also received considerable attention. The idea of relating distributional outcomes to school quality was a key element of the War on Poverty. Through schooling it was hoped that family poverty would not be transferred to the next generation - specifically, that high quality school investments could overcome deficits originating in the home. Researchers have focused on skill differences as being important in, for example, explaining the patterns of black-white earnings differences or the expansion of earnings differences among people with the same levels of schooling (e.g., O'Neill (1990); Juhn, Murphy, and Pierce (1991, 1993); Murphy and Welch (1992); Pierce and Welch (1996)). These analyses have emphasized the growing rewards to skills and have developed the implications of this for wage inequality. Owing to lack of sufficient data over time, they have mostly not looked directly at measured cognitive skills. ${ }^{2}$ Nonetheless, building on the findings about individual earnings, it is reasonable to conclude that variations in cognitive skills have a direct impact on variations in the distribution of incomes.

This discussion has concentrated on the importance of skill differences, particularly those measured by tests of cognitive knowledge. As such data have become available, research has underscored the importance of skills in determining economic outcomes for individuals. Thus, for the individual, research offers a clear answer to a fundamental question that has recently been voiced: Do differences in observed and measured achievement matter? Yes!

\footnotetext{
${ }^{2}$ Identifying the changing impact of measured ability on the distribution of outcomes over time is also a very difficult problem, particularly given the structure of available data; see Cawley et al. (2000), Heckman and Vytlacil (2001).
} 


\section{Economic growth}

The relationship between measured labor force quality and economic growth is perhaps even more important than the impact of human capital and school quality on individual productivity and incomes. Economic growth determines how much improvement will occur in the overall standard of living of society. Moreover, the education of each individual has the possibility of making others better off (in addition to the individual benefits just discussed). Specifically, a more educated society may lead to higher rates of invention; may make everybody more productive through the ability of firms to introduce new and better production methods; and may lead to more rapid introduction of new technologies. These "externalities" - influences on others of individual education outcomes - provide extra reason for being concerned about the quality of schooling. Because this is so important and because it has received little attention, we give this feature of the economy the most attention here.

The current economic position of the United States is largely the result of its strong and steady growth over the $20^{\text {th }}$ century. Strangely, over much of the period after World War II, economists did not pay as much attention to economic growth as they did to macroeconomic fluctuations. In the past 15 years, economists have returned to questions of economic growth. While a variety of models and ideas have been developed to explain differences in growth rates across countries (see Barro and Sala-I-Martin (1995)), they invariably include (but are not limited to) the importance of human capital. ${ }^{3}$

The effect of differences in growth rates on economic well-being is easy to see. Figure 1 begins with the value of gross domestic product (GDP) per capita in the year 2000 and shows its

\footnotetext{
${ }^{3}$ Some have questioned the precise role of schooling in growth. Easterly (2002), for example, notes that education without other facilitating factors such as functioning institutions for markets and legal systems may not have much impact. He argues that World Bank investments in schooling for less developed countries that do not ensure that the other attributes of modern economies are in place have been quite unproductive. As discussed below, schooling clearly interacts with other factors, and these other factors have been important in supporting U.S. growth.
} 


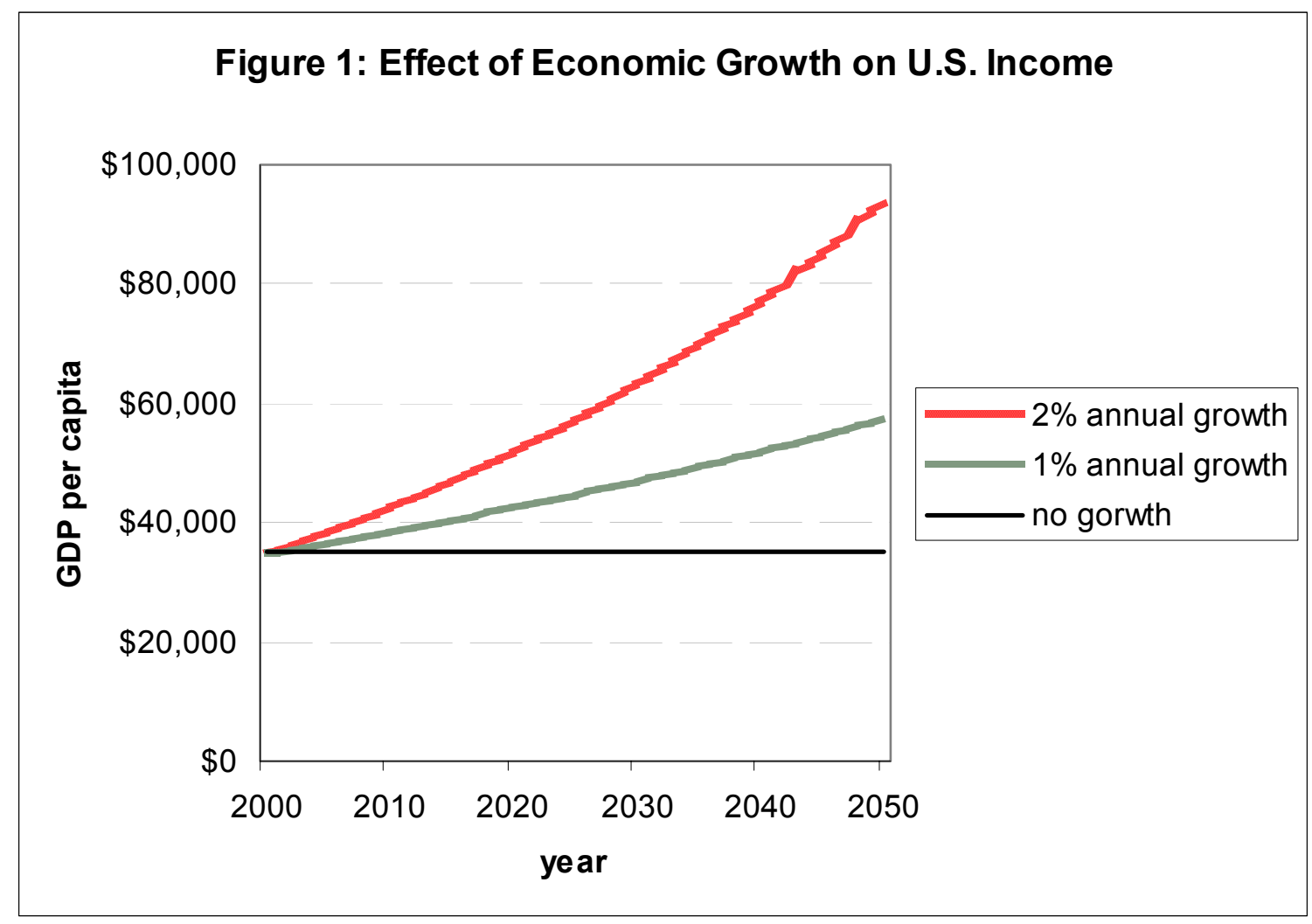


value in 2050 under different growth rates. If it grows at one percent each year, this measure of U.S. income would increase from $\$ 34,950$ to $\$ 57,480$ - or more than a 50 percent increase over the period. If it were to grow at two percent per year, it would reach $\$ 94,000$ in 2050 ! Small differences in growth rates have huge implications for the income and wealth of society.

The empirical work supporting growth analyses has emphasized school attainment differences across countries. Again, this is natural because, while compiling comparable data on many things for different countries is difficult, assessing quantity of schooling is more straightforward than most.

The typical study finds that quantity of schooling is highly related to economic growth rates. But, again, quantity of schooling is a very crude measure of the knowledge and cognitive skills of people. Few people would be willing to assume the amount learned during the sixth grade in a rural hut in a developing country equals that learned in an American sixth grade. Yet that is what is implicitly assumed when empirical analyses focus exclusively on differences in average years of schooling across countries.

Recent work by Dennis Kimko and me (Hanushek and Kimko (2000)) goes beyond that and delves into quality of schooling. We incorporate the information about international differences in mathematics and science knowledge that has been developed through testing over the past four decades. And we find a remarkable impact of differences in school quality on economic growth.

In 1963 and 1964, the International Association for the Evaluation of Education Achievement (IEA) administered the first of a series of mathematics tests to a voluntary group of countries. These assessments were subject to a variety of problems including: issues of developing an equivalent test across countries with different school structure, curricula, and language; issues of selectivity of the tested populations; and issues of selectivity of the nations that participated. The first tests did not document or even address these issues in any depth. 
These tests did, however, prove the feasibility of such testing and set in motion a process to expand and improve on the undertaking.

Subsequent testing, sponsored both by IEA and others, has included both math and science and has expanded on the group of countries that has been tested. In each, the general model has been to develop a common assessment instrument for different age groups of students and to work at obtaining a representative group of students taking the tests. An easy summary of the participating countries and their test performance is found in figure 2. This figure tracks performance aggregated across the age groups and subject area of the various tests and scaled to a common test mean of $50 .^{4}$ The United States and the United Kingdom are the only countries to participate in all of the testing. There is some movement across time of country performance on the tests, but for the one country that can be checked - the United States - the pattern is consistent with other data. The National Assessment of Educational Progress (NAEP) in the United States is designed to follow performance of U.S. students for different subjects and ages. NAEP performance over this period shows a sizable dip in the 1970s, a period of growth in the 1980s, and a leveling off in the 1990s. This pattern on NAEP, displayed in Appendix Figure A1 for 17year-olds in math and science, closely matches the international results and provides support for the validity of the international tests. ${ }^{5}$

Our analysis is very straightforward. We combine all of the available earlier test scores into a single composite measure of quality and consider statistical models that explain differences

\footnotetext{
${ }^{4}$ The details of the tests and aggregation can be found in Hanushek and Kimko (2000) and Hanushek and Kim (1995). This figure excludes the earliest administration and runs through the Third International Mathematics and Science Study (TIMSS) of 1995. Other international tests have been given and are not included in the figure. First, reading and literacy tests have been given in 1991 and very recently. The difficulty of unbiased testing of reading across languages plus the much greater attention attached to math and science both in the literature on individual earnings and in the theoretical growth literature led to the decision not to include these test results in the empirical analysis. Second, the more recent follow-on to the 1995 TIMSS in math and science is excluded from the figure simply for presentational reasons.

${ }^{5}$ The NAEP tests, like the international tests, consist of a series of separate examinations for different age groups. The NAEP patterns do differ some by age group with younger students showing more improvement than older ones. The same age differences hold in the international examinations, as shown in Figure 5 below, and the averaging across age groups buoys up the U.S. position in the aggregations of Figure 2.
} 
Figure 2. Normalized Test Scores on Mathematics and Science Examinations, 1970-1995

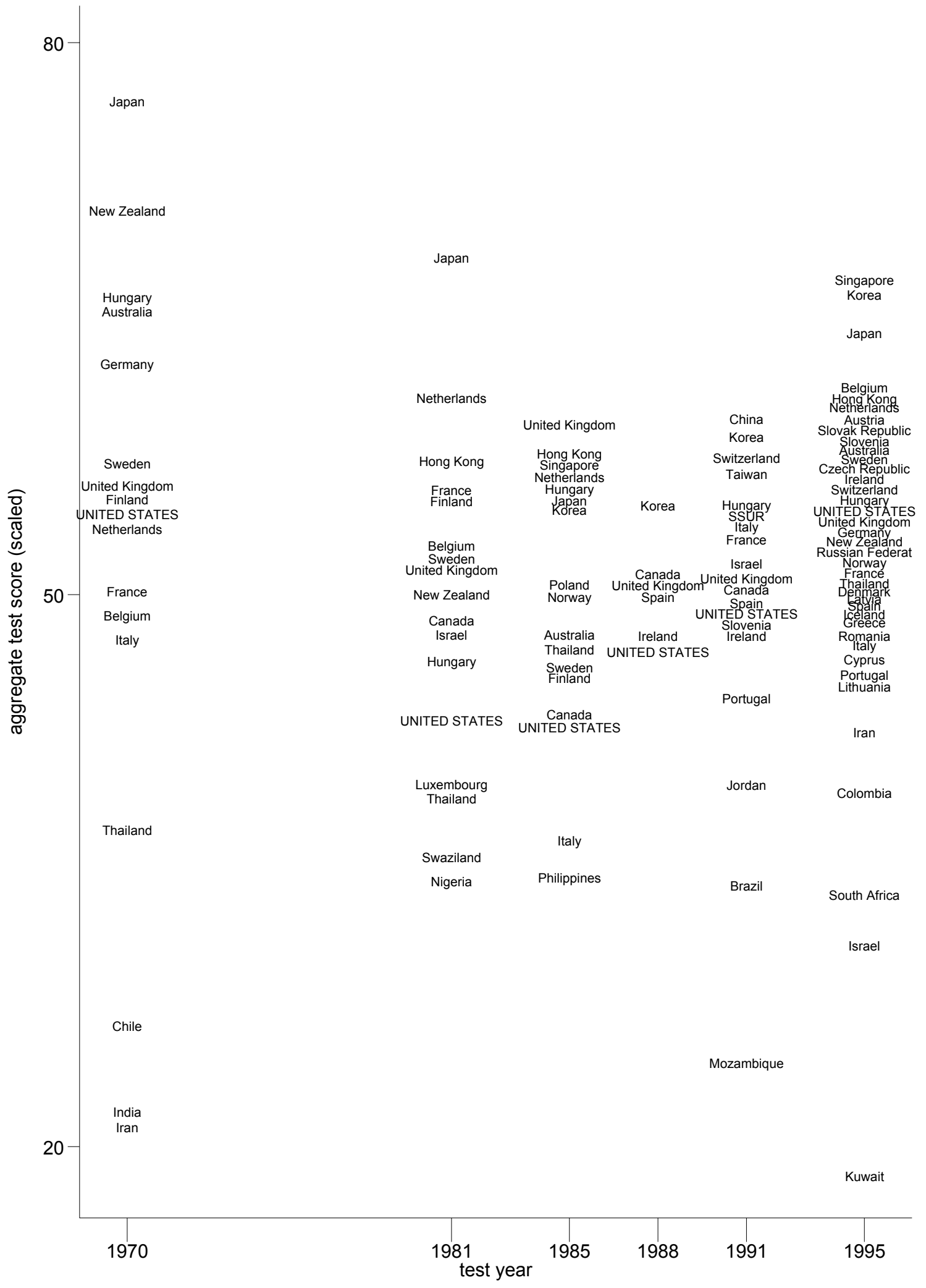


in growth rates across nations during the period 1960 to $1990 .{ }^{6}$ The basic statistical models, which include the level of income, the quantity of schooling, and population growth rates, explain a substantial portion of the variation in economic growth. Most importantly, the quality of the labor force as measured by math and science scores is extremely important.

One standard deviation difference on test performance is related to one percent difference in annual growth rates of per capita GDP. As shown in Figure 1, the impact of such a difference in growth rates is very large. One percent higher growth - say, two percent versus one percent per year growth - over a 50-year period yields incomes that are 64 percent higher!! Moreover, adding other factors potentially related to growth including aspects of international trade, private and public investment, and political instability leaves the effects of labor force quality unchanged.

One common concern in analysis such as this is that schooling might not be the actual cause of growth but, in fact, may just reflect other attributes of the economy that are beneficial to growth. For example, as seen in Figure 2, the East Asian countries consistently score very highly on the international tests, and they also had extraordinarily high growth over the 1960-1990 period. It may be that other aspects of these East Asian economies have driven their growth and that the statistical analysis of labor force quality simply is picking out these countries. Nonetheless, if the East Asian countries are excluded from the analysis, a strong - albeit slightly smaller - relationship is still observed with test performance. This test of sensitivity of the results seems to reflect a basic importance of quality, one that contributes also to the observed growth of East Asian countries.

Another concern might be that there are other factors that affect growth such as efficient market organizations are also associated with efficient and productive schools - so that again the test measures are really a proxy for other attributes of the country. In order to investigate this, we

\footnotetext{
${ }^{6}$ We exclude the two TIMSS tests from 1995 and 1999 because they were taken outside of the analytical period on economic growth. We combine the test measures over the 1965-1991 period into a single measure for each country. The underlying objective is to obtain a measure of quality for the labor force in the period during which growth is measured.
} 
concentrate on immigrants to the U.S. who received their education in their home countries. We find that immigrants who were schooled in countries that have higher scores on the international math and science examinations earn more in the United States. This analysis makes allowance for any differences in school attainment, labor market experience, or being native English language speakers. In other words, skill differences as measured by the international tests are clearly rewarded in the United States labor market, reinforcing the validity of the tests as a measure of individual skills and productivity.

Finally, the observed relationships could simply reflect reverse causality, i.e., that countries that are growing rapidly have the resources necessary to improve their schools and that better student performance is the result of growth, not the cause of growth. As a simple test of this, we investigated whether the international math and science test scores were systematically related to the resources devoted to the schools in the years prior to the tests. They were not. If anything, we found relatively better performance in those countries spending less on their schools.

In sum, the relationship between math and science skills on the one hand and productivity and growth on the other comes through clearly when investigated in a systematic manner across countries. This finding underscores the importance of high quality schooling and leads to a more detailed consideration of the growth of the United States economy.

\section{Why has U.S. growth been so strong?}

We started this discussion by recounting America's successful economic growth during the $20^{\text {th }}$ Century. Yet, looking at Figure 2, we see that the U.S. has been at best mediocre in mathematics and science ability. Regardless of the set of countries taking the test, the United States has performed in the middle of the pack or below. Some people find this anomalous. How 
could math and science ability be important in light of the strong U.S. growth over a long period of time?

The answer is that quality of the labor force is just one aspect of the economy that enters into the determination of growth. A variety of factors clearly contribute, and work to overcome any deficits in quality. ${ }^{7}$ Nonetheless, just because American growth has been strong, the schools remain a concern. Better schools would, by the available evidence, reinforce and amplify the other advantages that have supported the strong and consistent growth of the U.S. economy.

This section describes some of the other contributing factors. It does this in part to understand more fully the character of economic growth but more importantly because it highlights some issues that are important for thinking about future policies.

\section{Economic structure}

Almost certainly the most important factor sustaining the growth of the U.S. economy is the openness and fluidity of its markets. The U.S. maintains generally freer labor and product markets than most countries in the world. The government generally has less regulation on firms (both in terms of labor regulations and in terms of overall production), and trade unions are less extensive than those in many other countries. Even broader, the U.S. has less intrusion of government in the operation of the economy - not only less regulation but also lower tax rates and minimal government production through nationalized industries. These factors encourage investment, permit the rapid development of new products and activities by firms, and allow U.S. workers to adjust to new opportunities. While identifying the precise importance of these factors is difficult, a variety of analyses suggest that such market differences could be very important

\footnotetext{
${ }^{7}$ These other factors may also be necessary for growth. In other words, simply providing more or higher quality schooling may yield little in the way of economic growth in the absence of other elements such as the appropriate market, legal, and governmental institutions to support a functioning modern economy. Past experiences investing in less developed countries that lack these institutional features demonstrates that schooling is not itself a sufficient engine of growth.
} 
explanations for differences in growth rates (see, for example, Krueger (1974); World Bank (1993); Parente and Prescott (1994, 1999)).

Because of the generally favorable institutional conditions, U.S. growth has been strong, even if some of the underlying factors are not as competitive. In other words, the economic structure can mask problems within the economy. But this does not deny the fact that improving our schools and the quality of our labor force would enhance growth and incomes.

\section{Substitution of quantity for quality}

Over the $20^{\text {th }}$ century, the expansion of the education system in the United States outpaced that around the world. The United States pushed to open secondary schools to all citizens. With this came also a move to expand higher education with the development of land grant universities, the G.I. bill, and direct grants and loans to students. In comparison to other nations of the world, the United States labor force has been better educated even allowing for the lesser achievement of its graduates. In other words, more schooling with less learning each year has yielded more human capital than found in other nations that have less schooling but learn more in each of those years.

This historical approach, however, appears on the verge of reaching its limits. Other nations of the world, both developed and developing, have rapidly expanded their schooling systems, and many now surpass the United States. Figure 3 shows secondary school completion rates for both OECD countries and a selection of others in $1999 .{ }^{8}$ Remarkably, the United States trails a large number of other countries in 1999 and falls just slightly below the OECD average completion rate. The United States gains some by having rates of college attendance above the typical OECD country. Nonetheless, as summarized in Figure 4, U.S. students are not likely to complete more schooling than a significant number of other developed and developing countries.

\footnotetext{
${ }^{8}$ Data come from Organisation for Economic Co-operation and Development (2001), which has made an effort to use standardized definitions. The nonOECD countries are included in the World Education Indicators project.
} 
Fig. 3: Secondary school completion rates, 1999

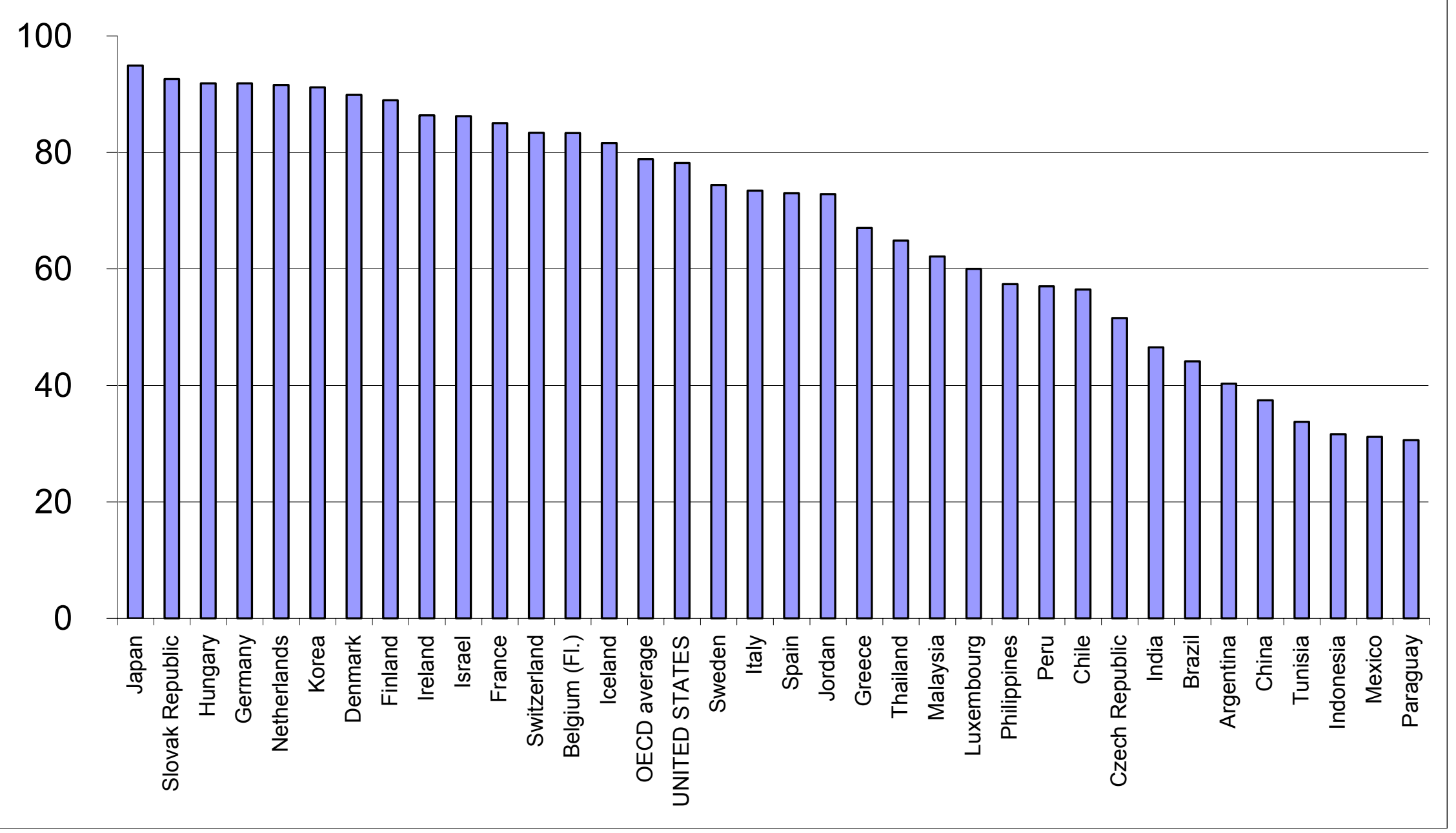


Fig. 4: Expected years of schooling, 1999

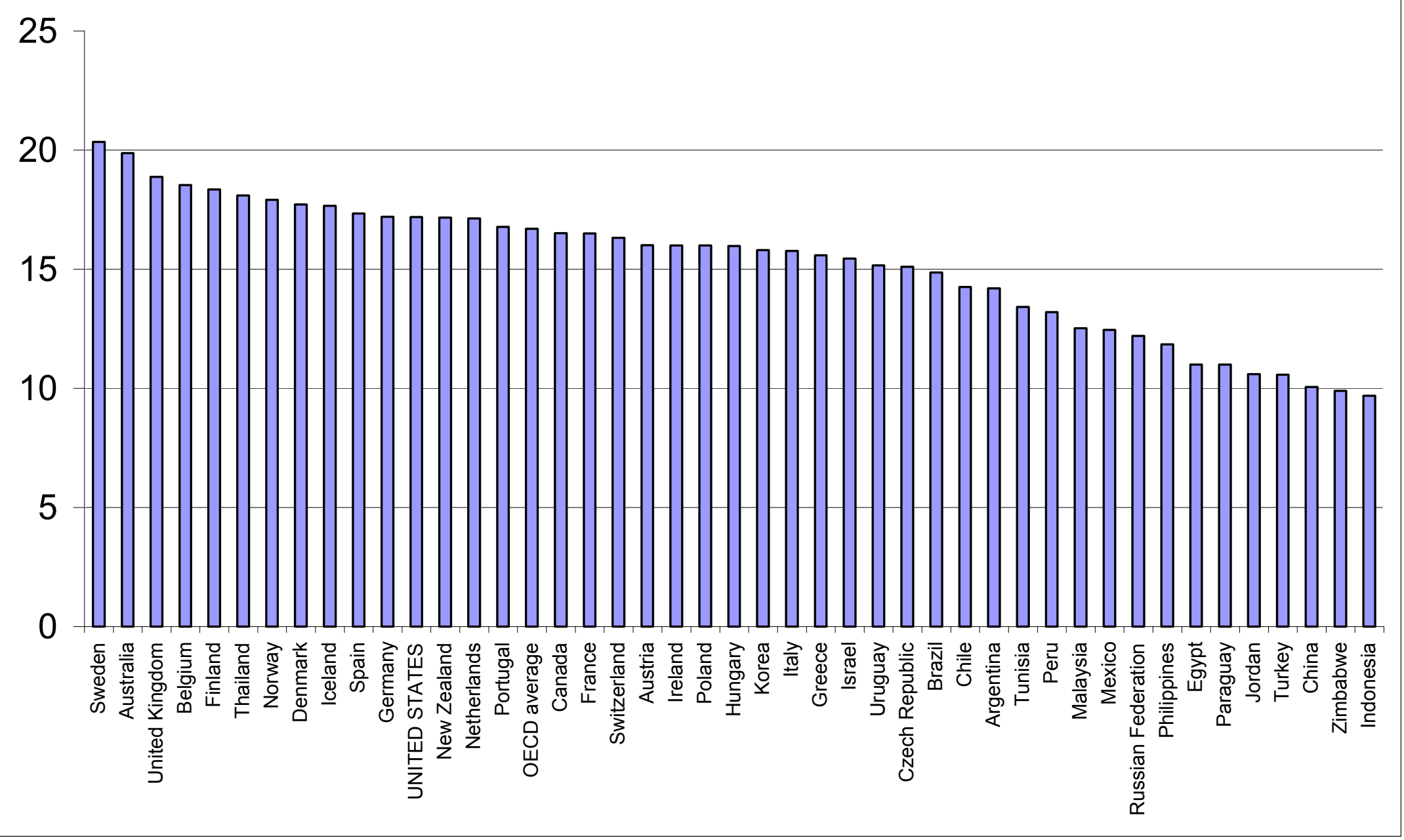


The past advantage of the United States in amount of school completed has gone away as other nations discovered the importance of schooling. Thus, going into the future, the U.S. appears unlikely to continue dominating others in human capital unless it can improve on the quality dimension.

\section{Quality of U.S. colleges}

The analysis of growth rates across countries emphasizes quality of the elementary and secondary schools of the United States. It did not include any measures of the quality of U.S. colleges. By most evaluations, U.S. colleges and universities rank at the very top in the world. No direct measurements of quality of colleges across countries exist. However, there is indirect evidence. Foreign students by all accounts are not tempted to emigrate to the U.S. to attend elementary and secondary schools - except perhaps if they see this as a way of gaining entry into the country. They do emigrate in large numbers to attend U.S. colleges and universities. They even tend to pay full, unsubsidized tuitions at U.S. colleges, something that many fewer American citizens do.

A number of the economic models of economic growth in fact emphasize the importance of scientists and engineers as a key ingredient to growth. By these views, the technically trained college students who contribute to invention and to development of new products provide a special element to the growth equation. Here, again, the United States appears to have the best programs. If this view is correct, U.S. higher education may continue to provide a noticeable advantage over other countries.

But the raw material for U.S. colleges is the graduates of our elementary and secondary schools. As has been frequently noted, the lack of preparation of our students leads to extensive remedial education at the postsecondary level, detracting from the ability of colleges and universities to be most effective. 


\section{Interpreting the Evidence on Quality}

The measurement of student outcomes has been pulled in two different directions. On the one hand, the movement toward standards and testing has emphasized the need to test student performance and to use information from those tests in judging the accomplishments of both students and schools. On the other hand, a segment of the school policy community has argued against the current testing - either because it does not measure attributes they think are important or because the test outcomes are irrelevant.

One aspect of this discussion is to demonstrate that differences in performance on existing tests have significant implications for both individual and aggregate success. Performance on standardized tests of math and science is directly related in individual productivity and earnings and to national economic growth.

None of this says that the existing tests are the best possible. It just indicates that the existing tests indicate something real, something that has important ramifications for individuals and the economy. ${ }^{9}$

Further, just because this dimension is important does not mean that other dimensions could not also be important. In fact, some research suggests that there are other important quality dimensions for individuals (e.g., Murnane et al. (2001)). Similarly, to the extent that aggregate growth is fueled by invention, creativity is likely to be important, and this may differ from measured cognitive skills. To be useful, however, these other dimensions must be identified and measured, and thought and analysis must go into determining how these dimensions might be improved. Currently a variety of people argue that schools do more than produce reading, math, and science - which schools undoubtedly do. But such arguments do not deny that cognitive

\footnotetext{
${ }^{9}$ Note, however, that most of the existing analysis has relied on test results where the scores might be regarded as a reflection of the student's true ability. It goes without saying that, if tests were artificially inflated, say by cheating or emphasizing just the mechanics of test taking, they would not reflect skill differences. In such a case, the relationship between measured scores and economic outcomes might disappear.
} 
skills are also important. And they do not say what should be done if one wants to enhance these other, currently unmeasured areas. ${ }^{10}$

Finally, this discussion has not pursued the issue of where the measured skills come from. We have learned through extensive research that families, schools, and others contribute to the knowledge of students. The foregoing analysis has simply considered the skills of individuals and how those skills translate into economic outcomes. The issue facing the United States is how to align policies that will enhance those outcomes.

It is interesting in this light that international evidence, like that for the United States, does not show test scores being strongly related to school resources. ${ }^{11}$ As mentioned previously, the international math and science scores used in the analysis of growth rates are not related to spending or other measures school resources such as pupil-teacher ratios (Hanushek and Kimko (2000)). These statistical results simply reinforce well known differences such as the very large class sizes in East Asian countries. Similarly, looking within countries that participated in the 1995 TIMSS, there is no systematic pattern to resource usage within these countries and student performance (Hanushek and Luque (2003)).

In contrast, a large body of evidence suggests that schools do have a large influence on student outcomes (see review in Hanushek (2002)). It is just that high quality schools are not just those that spend the most or have the smallest class sizes.

One final aspect of U.S. performance is important. United States students start out doing well in elementary grades and then fade by the end of high school. Figure 5 shows the slip that occurs over time in comparison to other countries participating in the TIMSS math and science

\footnotetext{
${ }^{10}$ Bracey (2002) phrases his discussion in terms of "competitiveness," measured by the Current Competitiveness Index developed by the World Economic Forum. He correlates this index with current scores on the Third International Mathematics and Science Study (TIMSS). The most telling points, he believes, are that TIMSS scores are not perfectly correlated with this index and that the U.S. ranks highly on the index. He goes on to explain why the United States ranks well on the competitiveness index by essentially the factors discussed for growth rate differences: higher quantity of education, greater college attendance, retaining our scientists and engineers (while attracting foreign immigrants), securing favorable rankings of its economy by international businessmen, and having greater innovative capacity.

${ }^{11}$ For the U.S. evidence on resources, see Hanushek (1997, 1999).
} 


\section{Figure 5: Performance on TIMSS by age groups}

TIMSS Scores

U.S. scores

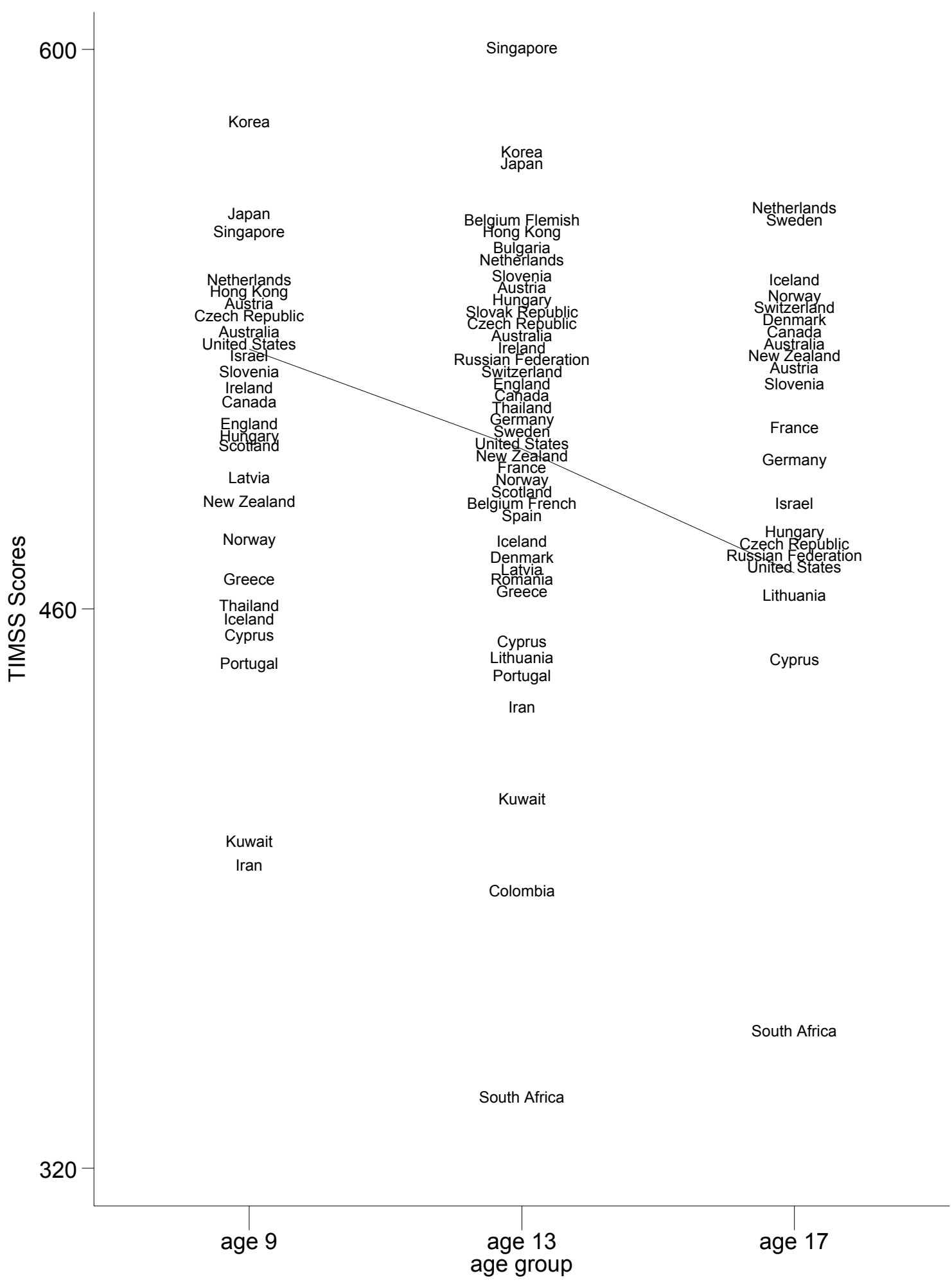


testing. To the extent that performance at the end of secondary schooling is the most important because it represents the input of college, because it sets the stage for science and engineering skills, or because it is important in its own right for workers in the labor force - schools in the United States are not keeping up in the preparation of students.

\section{Conclusions}

In February 1990 in an unprecedented meeting of the nation's governors with President George H. Bush, an ambitious set of goals was set for America's schools. Number 4 was that by the year 2000, "U.S. students will be first in the world in mathematics and science achievement." By 1997, as it was evident that this goal was not going to be met, President Clinton returned in his State of the Union speech to the old model of substituting quantity for quality: "We must make the 13th and 14th years of education -- at least two years of college -- just as universal in America by the 21 st century as a high school education is today" (Clinton (1997)). The quality goal, while perhaps more difficult to meet, appears to be the better approach than reverting to our past practice of emphasizing just quantity of schooling.

A variety of commentators, dead set against any fundamental changes in the nation's schools, rely on a combination of simplistic arguments: the poor performance of U.S. students does not matter because the tests are not valid; we could improve our scores if only we devote more resources to our public schools; or, schools cannot be expected to deal with the problems of learning that emanate from the home. Bracey (2002) goes one step further. He ends his discussion of how competitiveness of economies is uncorrelated with student performance by warning that innovation may be inversely related to student achievement: "We should think more than twice before we tinker too much with an educational system that encourages questioning. We won't benefit from one that idolizes high test scores. It could put our very competitiveness as a nation at risk." No evidence is presented, however, to demonstrate that creativity is lessened by 
improving the mathematics and scientific skills of students. Nor does he speak to the costs placed on those individuals who neither reap rewards for exceptional creativity nor have the skills necessary to perform in the modern economy.

Research underscores the long run importance of high achievement of our students and our future labor force. Higher achievement is associated both with greater individual productivity and earnings and with faster growth of the nation's economy. It no longer appears wise or even feasible to rely on more years of low quality schooling. 


\section{References}

Altonji, Joseph G., and Charles R. Pierret. 2001. "Employer learning and statistical discrimination." Quarterly Journal of Economics 116,no.1 (February):313-350.

Barro, Robert J., and Xavier Sala-I-Martin. 1995. Economic Growth. New York: McGraw-Hill, Inc.

Behrman, Jere R., Lori G. Kletzer, Michael S. McPherson, and Morton Owen Schapiro. 1998. "The microeconomics of college choice, careers, and wages: Measuring the impact of higher education." Annals of the American Academy of Political and Social Science 559(September):12-23.

Bishop, John. 1989. "Is the test score decline responsible for the productivity growth decline?" American Economic Review 79,no.1:178-197.

. 1991. "Achievement, test scores, and relative wages." In Workers and their wages, edited by Marvin H. Kosters. Washington, DC: The AEI Press:146-186.

Blackburn, McKinley L., and David Neumark. 1993. "Omitted-ability bias and the increase in the return to schooling." Journal of Labor Economics 11,no.3 (July):521-544.

- 1995. "Are OLS estimates of the return to schooling biased downward? Another look." Review of Economics and Statistics 77,no.2 (May):217-230.

Bracey, Gerald W. 2002. Why do we scapegoat the schools? Washington Post, May 5, 2002, B01.

Cawley, James, James J. Heckman, Lance Lochner, and Edward Vytlacil. 2000. "Understanding the role of cognitive ability in accounting for the recent rise in the economic return to education." In Meritocracy and economic inequality, edited by Kenneth Arrow, Samuel Bowles and Steven Durlauf. Princeton, NJ: Princeton University Press:230-265.

Clinton, William J. 1997. "State of the Union Address. Washington, DC.

Dugan, Dennis J. 1976. "Scholastic achievement: its determinants and effects in the education industry." In Education as an industry, edited by Joseph T. Froomkin, Dean T. Jamison and Roy Radner. Cambridge, MA: Ballinger:53-83.

Easterly, William. 2002. The elusive quest for growth: An economists' adventures and misadventures in the tropics. Cambridge, MA: The MIT Press.

Grogger, Jeffrey T., and Eric Eide. 1993. "Changes in college skills and the rise in the college wage premium." Journal of Human Resources 30,no.2 (Spring):280-310.

Hanushek, Eric A. 1997. "Assessing the effects of school resources on student performance: An update." Educational Evaluation and Policy Analysis 19,no.2 (Summer):141-164. 
- 1999. "The evidence on class size." In Earning and learning: How schools matter, edited by Susan E. Mayer and Paul E. Peterson. Washington, DC: Brookings Institution:131168.

_ 2002. "Publicly provided education." In Handbook of Public Economics, edited by Alan J. Auerbach and Martin Feldstein. Amsterdam: Elsevier.

Hanushek, Eric A., and Dongwook Kim. 1995. "Schooling, labor force quality, and economic growth." Working Paper 5399, National Bureau of Economic Research (December).

Hanushek, Eric A., and Dennis D. Kimko. 2000. "Schooling, labor force quality, and the growth of nations." American Economic Review 90,no.5 (December):1184-1208.

Hanushek, Eric A., and Javier A. Luque. 2003. "Efficiency and equity in schools around the world." Economics of Education Review 22,no.4 (August).

Hanushek, Eric A., and Richard R. Pace. 1995. "Who chooses to teach (and why)?" Economics of Education Review 14,no.2 (June):101-117.

Hanushek, Eric A., Steven G. Rivkin, and Lori L. Taylor. 1996. "Aggregation and the estimated effects of school resources." Review of Economics and Statistics 78,no.4 (November):611-627.

Heckman, James J., and Edward Vytlacil. 2001. "Identifying the role of cognitive ability in explaining the level of and change in the return to schooling." Review of Economics and Statistics 83,no.1 (February):1-12.

Juhn, Chinhui, Kevin M. Murphy, and Brooks Pierce. 1991. "Accounting for the slowdown in black-white wage convergence." In Workers and their wages, edited by Marvin $\mathrm{H}$. Kosters. Washington, DC: The AEI Press:107-143.

_. 1993. "Wage inequality and the rise in returns to skill." Journal of Political Economy 101,no.3 (June):410-442.

Kohn, Alfie. 2000. The Case Against Standardized Testing: Raising the Scores, Ruining the Schools: Heinemann.

Krueger, Anne O. 1974. "The political economy of the rent seeking society." American Economic Review 64,no.3 (June):291-303.

Manski, Charles F., and David A. Wise. 1983. College choice in America. Cambridge: Harvard University Press.

Murnane, Richard J., John B. Willett, M. Jay Braatz, and Yves Duhaldeborde. 2001. "Do different dimensions of male high school students' skills predict labor market success a decade later? Evidence from the NLSY." Economics of Education Review 20,no.4 (August):311-320.

Murnane, Richard J., John B. Willett, Yves Duhaldeborde, and John H. Tyler. 2000. "How important are the cognitive skills of teenagers in predicting subsequent earnings?" Journal of Policy Analysis and Management 19,no.4 (Fall):547-568. 
Murnane, Richard J., John B. Willett, and Frank Levy. 1995. "The growing importance of cognitive skills in wage determination." Review of Economics and Statistics 77,no.2 (May):251-266.

Murphy, Kevin M., and Finis Welch. 1992. "The structure of wages." Quarterly Journal of Economics 107,no.1 (February):285-326.

National Commission on Excellence in Education. 1983. A nation at risk: the imperative for educational reform. Washington, D.C.: U.S. Government Printing Office.

Neal, Derek A., and William R. Johnson. 1996. "The role of pre-market factors in black-white differences." Journal of Political Economy 104,no.5 (October):869-895.

O'Neill, June. 1990. "The role of human capital in earnings differences between black and white men." Journal of Economic Perspectives 4,no.4 (Fall):25-46.

Organisation for Economic Co-operation and Development. 2001. Education at a glance. Paris: Organization for Economic Co-operation and Development.

Parente, Stephen L., and Edward C. Prescott. 1994. "Barriers to technology adoption and development." Journal of Political Economy 102,no.2 (April):298-321.

_. 1999. "Monopoly rights: A barrier to riches." American Economic Review 89,no.5 (December):1216-1233.

Pierce, Brooks, and Finis Welch. 1996. "Changes in the structure of wages." In Improving America's schools: The role of incentives, edited by Eric A. Hanushek and Dale W. Jorgenson. Washington, DC: National Academy Press:53-73.

Rivkin, Steven G. 1995. "Black/white differences in schooling and employment." Journal of Human Resources 30,no.4 (Fall):826-852.

World Bank. 1993. The East Asian miracle: Economic growth and public policy. New York: Oxford University Press. 
Figure A1. National Assessment of

Educational Progress (NAEP), age 17

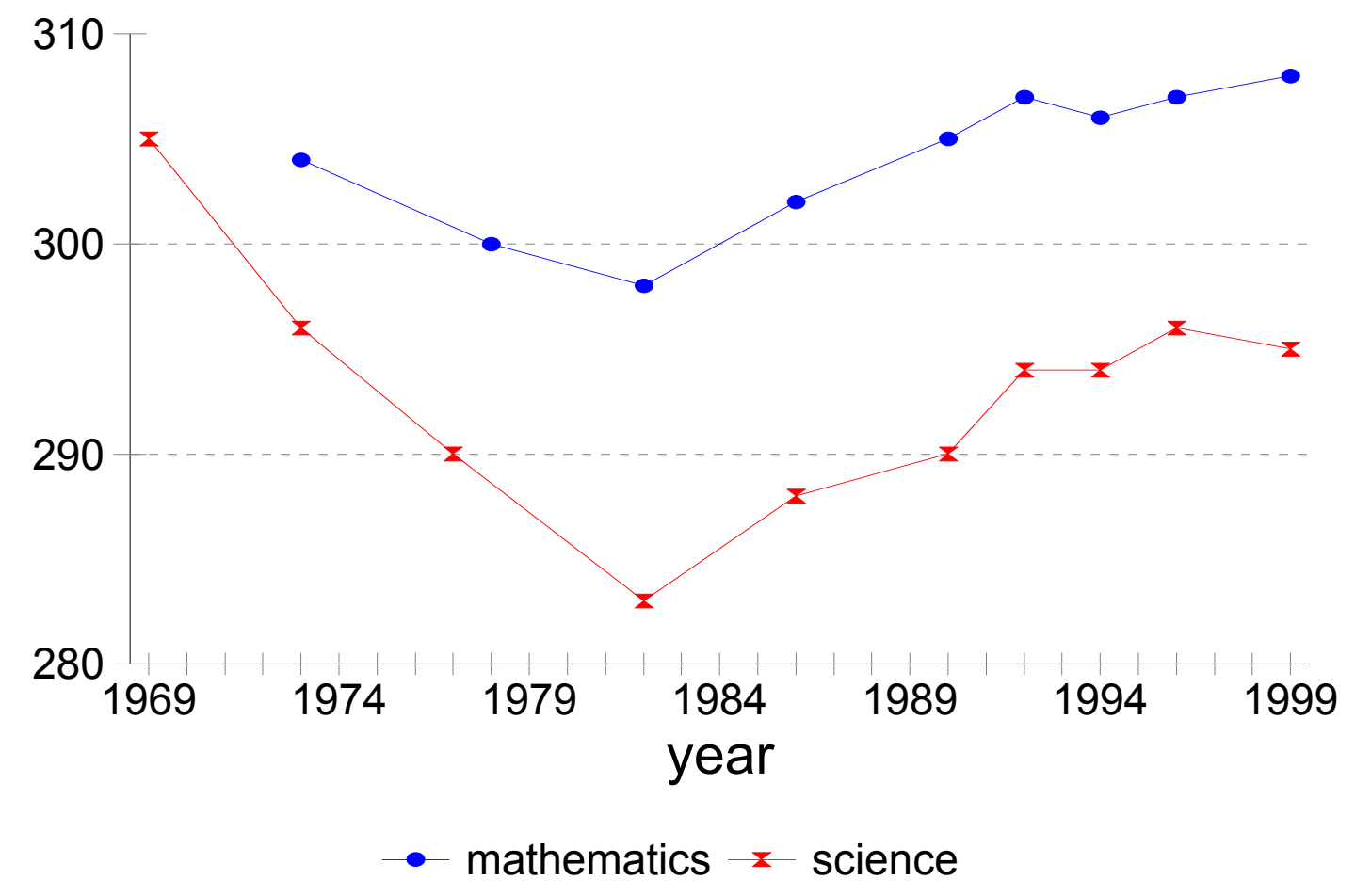

